\title{
SPATIO-TEMPORAL PATTERNS OF METEOROLOGICAL DROUGHTS IN THE BALEARIC ISLANDS (SPAIN)
}

\author{
J. LORENZO-LACRUZ* , E. MORÁN-TEJEDA
}

Department of Geography, University of the Balearic Islands. Spain.

\begin{abstract}
The Balearic Islands is a region highly prone to suffer meteorological and hydrological droughts, mainly due to the high intra- and inter-annual variability of precipitation, and the high water consumption associated to summer touristic pressure. In this work we aim to characterize the spatial and temporal characteristics of meteorological droughts in the region using a highdensity precipitation database for the three main islands. The "Standardized Precipitation Index - SPI" was calculated for each of the 50 precipitation series at the temporal scale of 12 months, which enabled pinpointing in time and space the main drought episodes from 1974 to 2014. Moreover, a Principal Component Analysis performed over the 50 12-month SPI series allowed us to identify two main patterns of drought variability, with a clear spatial distribution. The occurrence of droughts in the northern sector-including the Tramuntana mountain range (Majorca) and Minorca Island-was contrasted and independent to the occurrence of droughts in the southern areas. Similarly, the duration of droughts shows a decreasing trend for the northern region, and a slight increase for the southern stations. Two great drought episodes were identified, with a contrasted spatial propagation: The one in 1988-1991 affected mainly the northern region whereas in the south moist conditions prevailed; and the one occurred in 19992001, which affected the whole region but started its propagation from the south, and ended with extreme drought conditions in the eastern part of the territory. Results obtained highlight the need for studies of high spatial resolution in order to accurately assess the spatiotemporal patterns of meteorological droughts.
\end{abstract}

\section{Patrones espacio-temporales de las sequías meteorológicas en las Islas Baleares (España)}

RESUMEN. Con un clima caracterizado por la irregularidad de las precipitaciones tanto intra-como inter-anualmente, y una demanda de agua cuyo pico coincide con el del déficit hídrico estival, las islas Baleares son una región con un alto riesgo de ocurrencia de sequías. Gracias a una base de datos pluviométrica de gran densidad espacial, en este trabajo nos proponemos analizar los principales patrones de distribución espacial y de frecuencia temporal de las sequías meteorológicas en las tres grandes islas del archipiélago Balear. Para cada se- 
rie de precipitación (50) se ha calculado un índice de sequía, el "Standardized Precipitation Index”, computado a la escala temporal de 12 meses, lo cual nos ha permitido localizar en el tiempo y en el espacio los principales eventos de sequía meteorológica ocurridos desde 1974 a 2014. Asimismo, mediante un Análisis de Componentes Principales hemos identificado dos grandes patrones en la variabilidad temporal de las sequías, con una localización espacial muy determinada. Se puede afirmar que la ocurrencia de sequías en el sector norte de la región-coincidiendo con la Sierra de la Tramuntana (Mallorca) y la isla de Menorca-es diferenciada e independiente de la ocurrencia de sequías en el sector sur, aunque en alguna ocasión aislada se han producido sequías en todo el territorio. Del mismo modo hemos comprobado que la evolución de las características de las sequías (especialmente su duración) es contrastada entre las dos áreas: en el sector norte la duración de las sequías ha descendido durante el periodo estudiado, mientras que en el sector sur se aprecia una ligera tendencia hacia el incremento. Los dos mayores eventos de sequía registrados, 1988-91 y 1999-01, presentan una evolución diferenciada en cuanto a su propagación temporal; el primero afectando principalmente al norte de la región, mientras en el sur se establecían progresivamente condiciones húmedas; y el segundo episodio afectando a la totalidad del territorio, pero comenzando su avance desde el sur y terminando con condiciones de sequía extrema en toda la parte oriental de la región. Los resultados indican la importancia de análisis regionales de gran resolución espacial para evaluar con rigor el comportamiento espacio-temporal de las sequías meteorológicas.

Key words: Mediterranean region, meteorological drought, Standardized Precipitation Index (SPI), principal components analysis.

Palabras clave: región Mediterránea, sequía meteorológica, Índice de Precipitación Estandarizado (SPI), análisis de componentes principales.

Received 1 February 2016 Accepted 24 February 2016

*Corresponding author: J. Lorenzo-Lacruz, Department of Geography, University of the Balearic Islands. Ctra. de Valldemossa km 7.5, 07122 Palma de Mallorca, Balearic Islands, Spain. E-mail: j.lorenzo@uib.es

\section{Introduction}

Drought is, among all natural hazards, the one which affects more people than any other (Obasi, 1994), and causes negative impacts on different hydrological, ecological, economic and agricultural systems. In last decades, many European countries have suffered the adverse effects of droughts, including restrictions on water usage for urban consumption and leisure, reductions in electricity supply, crop production losses and increased forest fires (EEA, 2001). Different studies showed the great severity of droughts during the second half of the $20^{\text {th }}$ century, when the most extreme episodes in the last centuries were registered, especially in the Mediterranean region (Nicault et al., 
2008; Briffa et al., 2009). Climate models point to a general increase in warming and a pronounced decrease in precipitation by the end of the 21st century in the Mediterranean region, especially during spring and summer (Ragab et al., 2002; Sumner et al., 2003; Giorgi et al., 2008; Osca et al., 2013). Moreover, other studies have predicted higher inter-annual variability of precipitation (Sumner et al., 2003; Alpert et al., 2008) and an increase in the length of the dry season (Palutikof et al., 2004). In this context, Mediterranean islands are among the areas expected to be particularly affected by these changing conditions (Diffenbaugh et al., 2007). However, the spatial resolution of most climatic models introduce limitations when assessing and monitoring drought patterns in areas with high precipitation variability (e.g. Mediterranean climate area) or with a limited spatial extension (e.g. Balearic Islands). Moreover, future temperature projections are, in general, more accurate $\left( \pm 1^{\circ} \mathrm{C}\right)$ than those of precipitation $( \pm 25 \%)$ (García-Ruiz et al., 2011). For these reasons, the assessment and characterization of historical droughts using in-situ measurements has become essential in management of water resources (Mishra et al., 2010), and the application of the information obtained for the design of water management plans may compensate for the losses resulting from drought episodes (Quiroga et al., 2011).

The Balearic Islands present several characteristics which turn them into a particularly suitable area for drought analysis. The archipelago is a climatic ecotone area located in the transitional subtropical zone under Mediterranean climate conditions, where the effects of climate change are expected to be more intense than in other areas (Lavorel et al., 1998; Sumner et al., 2003; Diffenbaugh et al., 2007). It is also a zone where decreasing trends in precipitation, especially during spring, have been detected (Homar et al., 2010). Other peculiar characteristics of the Balearic Islands are the high variability of precipitation within a very limited spatial extension, a contrasting relief, a limited area for runoff generation, the inexistence of rivers or perennial streams and very high population density, especially during summer, when tourism pressure is evident (Hof et al., 2011). For these reasons, the Balearic Islands are a very vulnerable area during drought episodes that needs a deep knowledge and understanding of this natural risk in this spatial context.

In the last years, several studies have analyzed the spatiotemporal patterns of rainfall in the Iberian Peninsula (Esteban-Parra et al., 1998; Morata et al., 2006; Rodrigo et al., 2007; del Río et al., 2011; González-Hidalgo et al., 2011) and the Balearic Islands (Homar et al., 2010). Meteorological droughts in the Iberian Peninsula have been also a topic of great interest for the scientific community (Lana et al., 2001; Vicente-Serrano et al., 2004; Lana et al., 2006; Vicente-Serrano, 2006a; García-Herrera et al., 2007). However, little attention has been paid to the analysis of meteorological droughts in the Balearic Islands. In this study we addressed a comprehensive analysis of meteorological droughts in the Balearic Islands aimed to end with the lack of information on this topic in the area. We analyzed the spatio-temporal variability of meteorological droughts in the Balearic Islands during the last 40 years (1974-2014) using a very high-density precipitation database (50 stations over $4914 \mathrm{~km}^{2}$ ). We extracted the main temporal patterns of drought occurrence and pinpointed major drought episodes in order to analyze 
its characteristics (duration and intensity). Finally, we assessed the spatial coverage of droughts and explored the genesis and propagation of two major drought episodes.

\section{Study area}

The Balearic Islands are located in the western sector of the Mediterranean Sea, in front of the east coast of the Iberian Peninsula (Fig. 1). The archipelago is composed of 5 islands (Majorca, Minorca, Cabrera, Ibiza and Formentera) and dozens of islets, although in this study we only included Majorca, Minorca and Ibiza, due to climatic data availability. Majorca is the biggest Balearic Island and covers $3640 \mathrm{~km}^{2}$. There are three main relief units in Majorca: (i) the Levant Ranges in the east (N-S orientation) reach altitudes of 500 m.a.s.l.; (ii) the Tramuntana Range at the west and north part of the island, with an oblique orientation regarding the rest of units and a prominent role in the distribution of rainfall in Majorca; and (iii) the central plain between both ranges, which rarely exceeds 300 m.a.s.l. The Tramuntana Range is the main relief unit of the Balearic Islands and shows a parallel arrangement to the northwestern coast of Majorca. It has 89 kilometers of longitude and a mean width of 15 kilometers. Summit line exceeds 600 m.a.s.l. and the highest point is located at 1445 m.a.s.l. (Puig Major), although there are 10 summits higher than 1000 m.a.s.l. (Giménez et al., 2007). Menorca $\left(702 \mathrm{~km}^{2}\right)$ is the eastern and northernmost island of the archipelago. There are two main relief units separated by a sinuous line with a ESE-WNW orientation: the northern sector is composed by an uneven relief and numerous hills between 200 and 300 m.a.s.l.; and the southern sector, a platform with a gradual incline towards the sea, interspersed with ravines and intermittent streams. Ibiza $\left(572 \mathrm{~km}^{2}\right)$ is the closest island to the Iberian Peninsula. Two mountainous zones (400-500 m.a.s.1.) and two depressions with a general orientation ENE-WSW are the main relief units.

The location surrounded by sea, in a convergence zone between the air masses from the Rhône and Ebro valleys, and the general disposition of the relief, confers to the climate of the Balearic Islands a lot of particularities. The climate is Mediterranean in terms of temperature, characterized by hot summers and moderate winters. By contrast, the spatial and temporal patterns of precipitation are more complex. There is a steep pluviometric gradient in Majorca, where mean annual precipitation ranges from more than $1200 \mathrm{~mm}$ in the northern sector of the Tramuntana range to less than $300 \mathrm{~mm}$ in the southern part of the island (see Fig. 1). The spatial distribution of precipitation in the other islands is more homogeneous and ranges from 400 to $500 \mathrm{~mm} /$ year in Ibiza and from 500 to $600 \mathrm{~mm} /$ year in Minorca. In terms of the seasonal distribution, precipitation is mainly concentrated in autumn (especially in November), although it shows high variability between years (see Fig. 1). In summer precipitation is scarce, especially in the south of Majorca. Rainfall episodes are few and intense: around $70 \%$ of the annual precipitation is registered in less than 20 days (Jansà, 2014). The limited extension of the islands and its permeable lithology (meanly limestones and dolomites) reduces runoff generation, causing the inexistence of rivers or perennial streams, and water resources are stored in the numerous aquifers and in two little reservoirs in Majorca. 


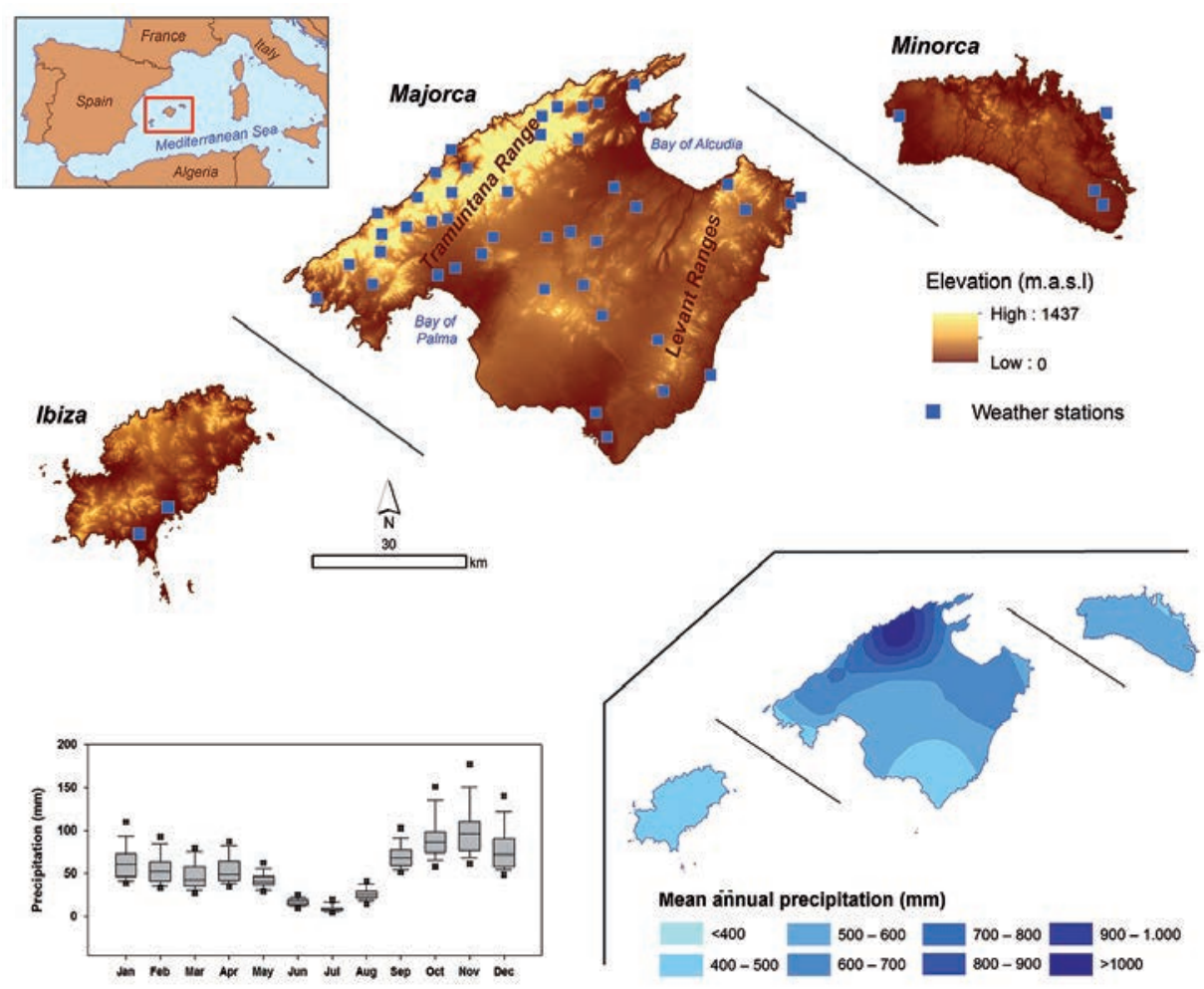

Figure 1. Balearic Islands: location (up left), topography and distribution of the weather stations used in the study (center), box-plots show mean monthly precipitation in the 50 stations analyzed (down left) and spatial distribution of mean annual precipitation during the study period (down right).

\section{Database and methods}

\subsection{Precipitation records: quality control, homogenization and gap-filling processes}

The analysis of meteorological droughts patterns in the Balearic Islands was based on the use of the Standardized Precipitation Index (McKee et al., 1993), computed at the scale of 12 months. For this reason it was necessary to use a robust and quality controlled monthly precipitation database, which encompassed the high spatiotemporal variability of precipitation in the Balearic Islands (see Fig. 1). We computed monthly sums over 94 daily precipitation series provided by the Spanish Meteorological Agency (AEMET). Since the length of the series and the presence of gaps were variable, and because we aimed for a balance between spatial and temporal coverage, we selected a set of 50 series with less than $10 \%$ of missing records between 
1974 and 2014 (see the distribution of the weather stations in Fig. 1). In this way we included precipitation series of the three major Balearic Islands (Majorca, Minorca and Ibiza) and 40 years of monthly records, providing a representative sample to perform the analysis (WMO, 2011). The protocol followed to assess data quality was the same used in several studies addressed in this region with satisfactory results (see González-Hidalgo et al., 2011 for more details). The whole process was based on the iterative use of reference series and included detection of anomalous data using ratios, performance of relative homogenization tests (Alexandersson, 1986) and gap-filling.

\subsection{Standardized Precipitation Index (SPI)}

The Standardized Precipitation Index (SPI) is becoming one of the most used indices worldwide for meteorological drought monitoring and impact assessment, and it is considered to be a universal reference drought index by the World Meteorological Organization (Hayes et al., 2011). The SPI has proved its ability to quantify drought severity at different time scales, and provides a powerful tool for the analysis and monitoring of meteorological droughts (Lana et al., 2001; Bonaccorso et al., 2003; Patel et al., 2007; Di Lena et al., 2014) and for the assessment of drought impacts on different systems, including river flows and reservoir storages (Vicente-Serrano et al., 2005; Lorenzo-Lacruz et al., 2010; Hannaford et al., 2011; Lorenzo-Lacruz et al., 2013a), vegetation activity (Pasho et al., 2011; Vicente-Serrano et al., 2012; Morán-Tejeda et al., 2013), soil moisture (Sims et al., 2002; Hirschi et al., 2011) and spring discharges and groundwater levels (Fiorillo et al., 2010).

The SPI transforms precipitation series into series of anomalies expressed as $\mathrm{Z}$-scores (with a mean equal to 0 and a standard deviation equal to 1 ), and accumulates the precipitation deficits of different temporal duration. In this study we used the algorithm developed by Vicente-Serrano (2006b) to calculate the SPI at different time scales, basing the calculation on the fit of the precipitation series to the Pearson III distribution (see also Guttman, 1990; Quiring, 2009). We calculated the SPI from the precipitation series of 50 Balearic weather stations from January 1974 to December 2014 at a temporal scale of 12 months (SPI-12). This SPI time scale avoids intraannual frequency variations and it was already effectively used for meteorological drought assessment in the Iberian Peninsula (Vicente-Serrano, 2006a) and in the region of Valencia (Vicente-Serrano et al., 2004), the closest continental land with available precipitation records to our study area. Using the SPI-12 we also carried out a dry spell analysis to define meteorological drought episodes (using a threshold) in order to highlight its hazardous parameters: duration (defined as the number of consecutive months under moderate drought conditions; SPI $<-0,84$, corresponding to $20^{\text {th }}$ percentile) and intensity (ratio between the accumulated deficit expressed as SPI units and the duration of the episode). SPI thresholds selected to classify droughts into categories were taken from Agnew (2000), who suggested a more suitable classification for the study area than the original proposed by McKee et al. (1993). 


\subsection{Principal Components Analysis}

An exploratory analysis was performed to search for common patterns in the evolution of meteorological droughts in the Balearic Islands. This was done using a Principal Component Analysis (PCA) in S mode (with the SPI-12 series from the 50 stations as input variables). This technique enables detection of autocorrelation in the sample of variables (through a correlation matrix), and constructs new orthogonal (non-correlated) variables, termed principal components (PCs), which are lineal combinations of the original variables, and capture most of the original variance in the data (Jolliffe 2005). To facilitate the interpretation of the resulting PCs (i.e. the basic modes of variability in SPI), we performed a varimax rotation of the axis (White et al., 1991), which enabled their approximation to the original variables to be maximized in order to obtain more physically robust patterns (Richman, 1986).

\section{Results}

\subsection{General patterns of meteorological droughts}

Figure 2 summarizes the results of the PCA performed on the SPI-12 series: the temporal evolution of the scores of the first and second principal component (PC1, PC2) and the spatial distribution of the loadings (correlations) between each PC and the SPI-12 at each weather station are shown. PC1 explained $39 \%$ of the total variance and show three contrasting periods in its evolution: a first humid period from 1974 to 1982 , a prolonged dry period from 1982 to 2002 (with sporadic humid episodes intercalated between the major dry episodes) and a final humid period lasting until 2014. All drought episodes recorded between 1982 and 2002 were prolonged in time and they reach peaks of intensity in 1983 and 1989. The correlations between this temporal signature and the SPI-12 series were very high for those stations located in the southern part of the Tramuntana Range (west of Majorca) and high for the northern sector of the Tramuntana Range and Minorca. PC2 explained 35\% of the total variance and show a higher frequency in the alternation between dry and moist periods than PC1. General dry conditions predominated during the decade of 1980 and from 1993 to 2003, and both dry periods were preceded and followed by enhanced humid periods. In the last decade the most relevant drought episode was registered during 2007. The most intense episode occurred around 2000, although secondary and severe episodes were registered during the whole study period. Weather stations showing high correlations between PC2 and the SPI-12 series are located in the center and east of Majorca and Ibiza, and middle correlations can be found in the north of Majorca and Minorca. The most important drought episode of PC2 registered in 2000 coincides in time with a major drought episode of PC1. Nevertheless, whereas stations correlated with PC2 showed especially humid conditions between 1989 and 1992, those ones correlated with PC1 were suffering an intense and long-lasting drought episode, highlighting the contrasting evolution and occurrence of droughts between PC1 and PC2. 


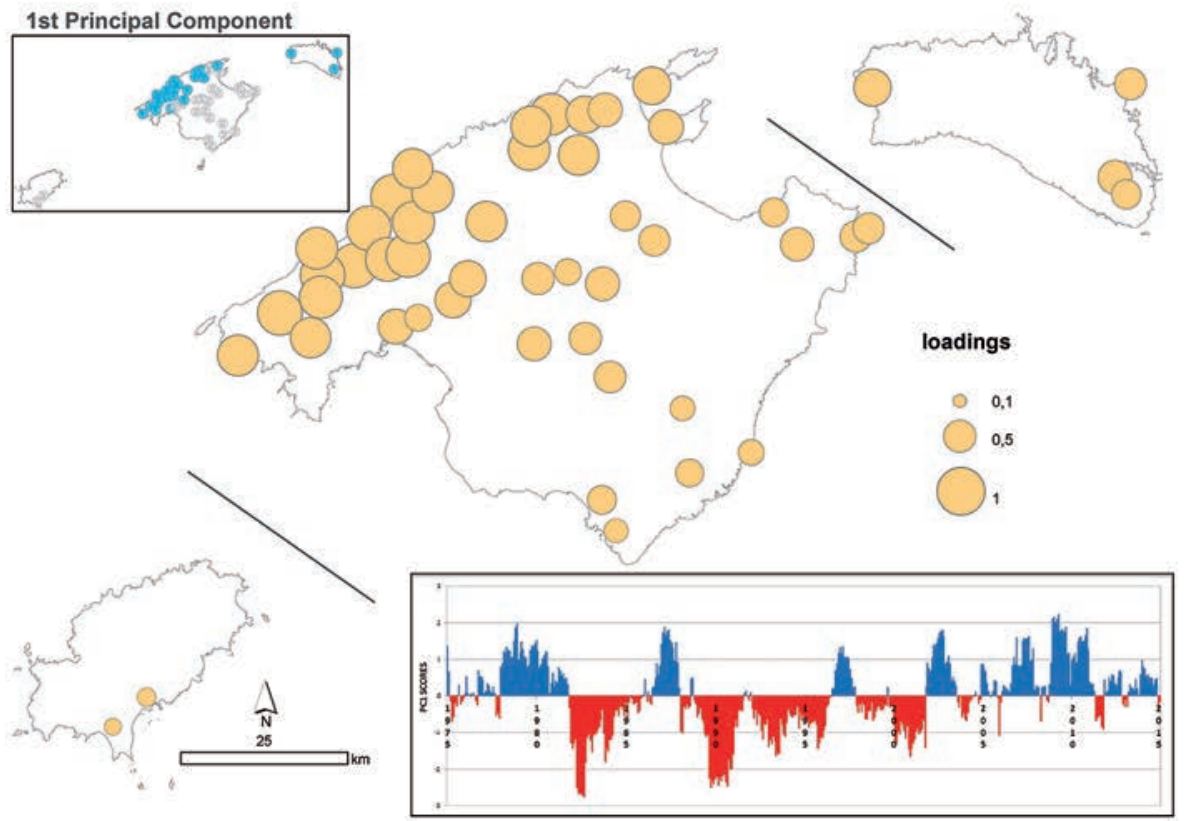

2nd Principal Component

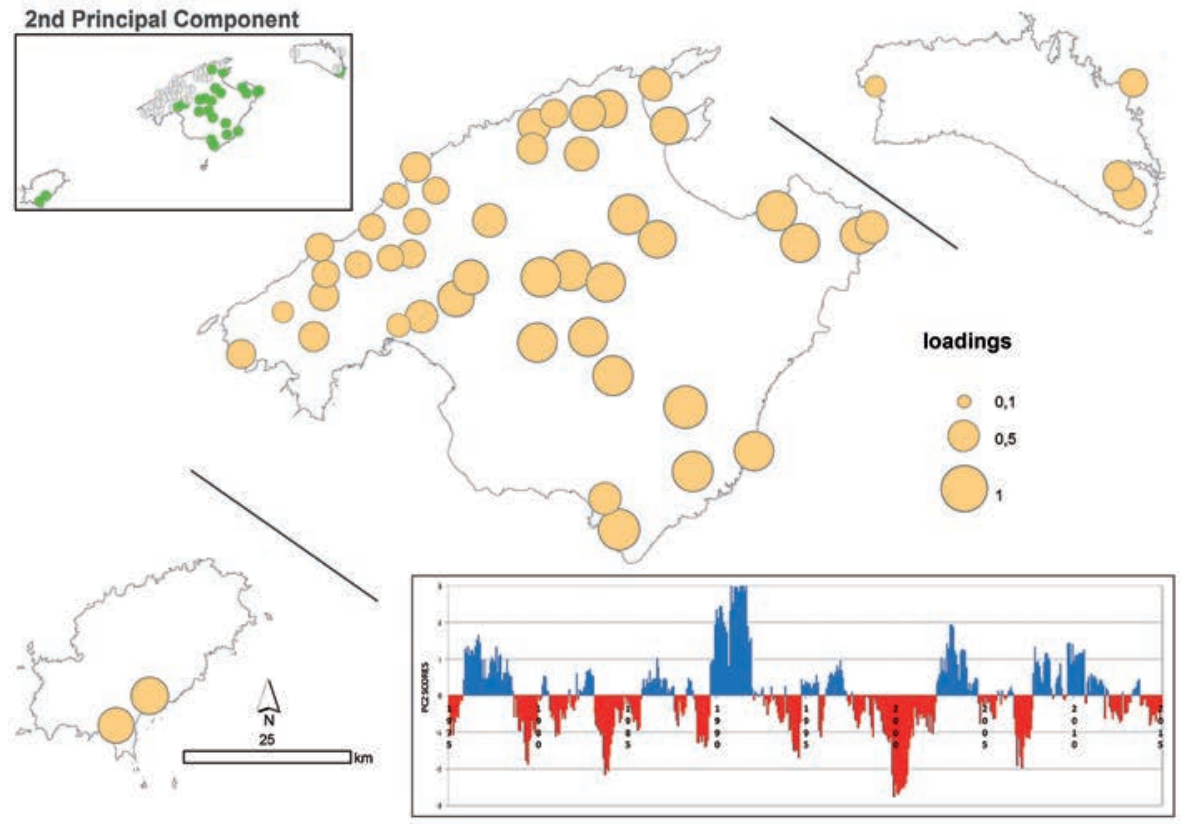

Figure 2. Up: spatial distribution of the PCA loadings and temporal evolution of the scores of the 1st Principal Component. Down: spatial distribution of the PCA loadings and temporal evolution of the scores of the 2nd Principal Component. Minor maps show the most correlated PC (PCl blue; PC2 green). 


\subsection{Characteristics of drought episode}

Figure 3 plots the characteristics of the main droughts recorded for each PC, namely duration and intensity, versus time. As previously highlighted, major drought episodes registered for $\mathrm{PC} 1$ do not coincide on time with those registered for PC2, except the one recorded in 2000 which happened for both PCs, that is, in the whole territory. There are no clear differences between PCs regarding duration and intensity of droughts. The duration of most drought episodes lays within the range of 3-12 months with the exception of three episodes that lasted 20 or more months. The same happens with intensity (accumulated SPI deficits divided by number of months of the episode) with most episodes recording similar values. At this regard, it is remarkable that the three most intense episodes are the same ones with longer duration (top of the plot), which indicates the high severity of water deficit suffered during these episodes, especially the one that occurred in 2000, which as previously stated, covered most of the territory. Last but not least, figure 3 allows observing a contrasting evolution in the duration of droughts between PCs. Although they cannot be considered as robust linear trends, the fitted polynomial curves indicate a decrease in drought duration on time for PC1 and a slight increase in drought duration for PC2, reinforcing the finding of the two contrasted spatial patterns of droughts in the islands.

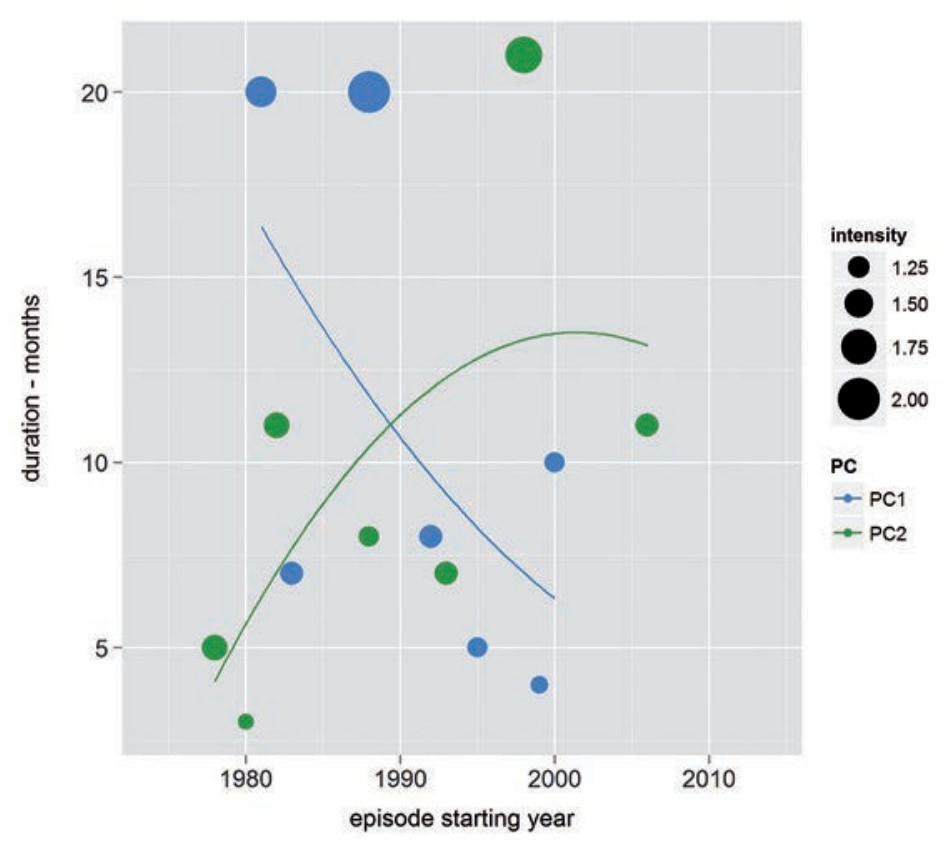

Figure 3. Duration and intensity of drought episodes versus time. The size of the dots indicate the intensity of episodes, this is, the total accumulated SPI deficit divided by the number of months of the episode. The curves correspond to $2^{\text {nd }}$ degree polynomial fitting of drought duration versus time. 


\subsection{Droughts spatial coverage}

Figure 4 shows the evolution of the percentage of weather stations affected by moderate drought (SPI <-0.84), severe drought (SPI < -1.28) and extreme droughts (SPI <-1.65). Three main periods are evident in this evolution. During the first one, between 1974 and 1982, the area affected by moderate drought conditions rarely exceeded $20 \%$ of the study area. The second stage, between 1982 and 2002, is characterized by recurrent drought episodes covering more than $70 \%$ of the analyzed stations. Nevertheless, there are substantial differences between the spatial extension of moderate and extreme droughts during the decade of 1990 and the rest of the study period: the maximum percentage of stations under extreme drought conditions during the decade of 1990 was around $30 \%$, whereas during the other major drought episodes (1982-1983 and 2000-2001) this figure reached 50\% and 60\% with occasional values over 80\%. The third stage, between 2002 and 2014 was a humid period where the percentage of stations under extreme drought conditions never exceeded $10 \%$ and moderate drought conditions were rarely recorded in more than $30 \%$ of the analyzed stations.

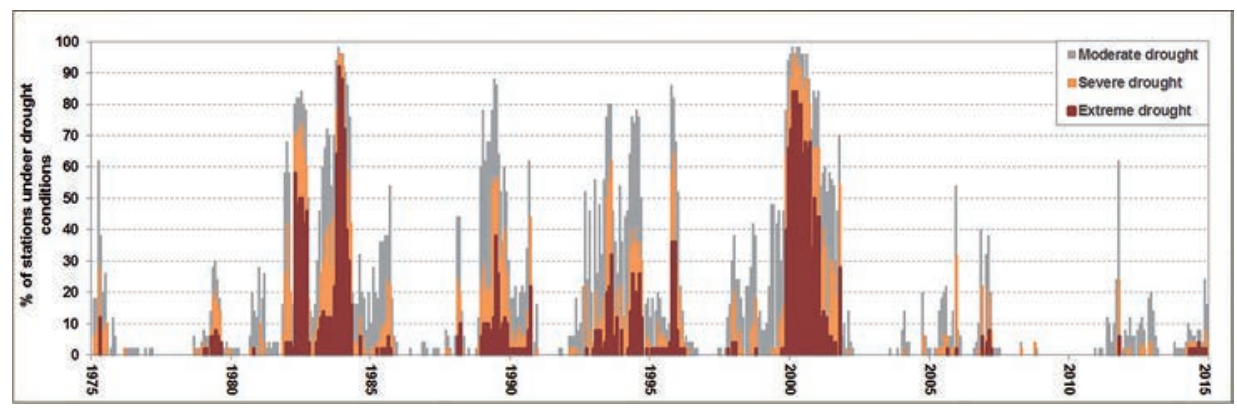

Figure 4. Evolution of percentage of weather stations affected by droughts: moderate drought $($ SPI $<-0.84$; grey), severe drought $(S P I<-1.28$; orange) and extreme drought (SPI $<-1.65$; red).

The above analysis highlights the spatial complexity of meteorological droughts in the Balearic Islands, summarized in the contrasted evolution of PC1 and PC2 and the differences in the percentage of weather stations under different drought conditions through time. Thus, individual drought episodes can vary and present different spatial features in terms of the onset, intensity, spatial propagation and area affected. Figure 5 shows the genesis, spatial propagation and disappearance of the 1999-2001 drought episode, selected in terms of its intensity and for its simultaneous occurrence in both PCs. The genesis of this episode was in July 1999 in the central sector of Majorca and Ibiza. In October 1999 drought extent shifted to north and severe drought conditions covered Minorca and moderate drought the eastern part of Majorca. In January 2000 the episode reached its greatest intensity and almost the entire Majorca and Ibiza were under extreme drought conditions, whereas Minorca suffered severe drought conditions. This situation remained almost unchanged until October 2000, when drought conditions disappeared from Minorca and the northernmost sector of Majorca. 
This pattern was sustained until July 2001, when drought weakened also in Ibiza and the central sector of Majorca. During autumn 2001 there was a reinforcement of the drought episode in the north and the east of Majorca and Ibiza. This major drought episode ended in January 2002, when normal conditions covered the three islands.

Figure 6 shows the spatial evolution of the 1989-1990 drought episode. This episode was selected because in previous sections we found a very contrasting temporal evolution of PC1 and PC2 during it, and we consider relevant to deepen in the understanding of different drought spatial patterns in a limited extension, such as the Balearic Islands. The 1988-1990 episode began in autumn 1988 and by January 1989 moderate drought conditions spread along the three islands, with higher intensity in the northern sector of Majorca and the east of Minorca. The extension of drought conditions remained unaltered until October 1989 when drought weakened in the center and east of Majorca and Ibiza and normal conditions appeared there, whereas the Tramuntana Range and Minorca remained under severe and extreme drought conditions. The contrasted extent of this drought episode at this moment coincides with the spatial distribution of the stations most correlated with PC1 and PC2. This dichotomous spatial pattern was maintained for a year until the total disappearance of drought conditions in the Tramuntana Range and Minorca in October 1990. During this year until April 1991 humid conditions were progressively spreading along the eastern part of Majorca and Ibiza.

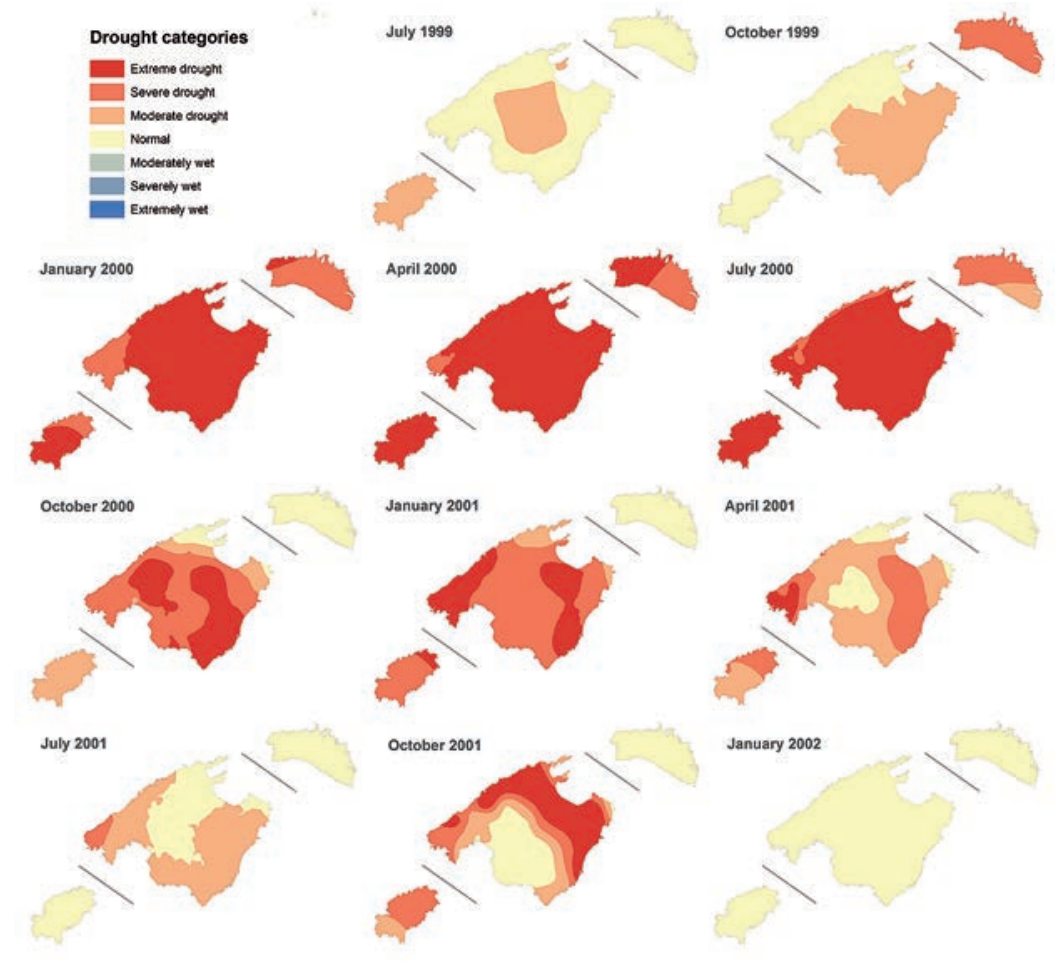

Figure 5. Spatial patterns of the SPI-12 series during the 1989-1990 major drought episode. 


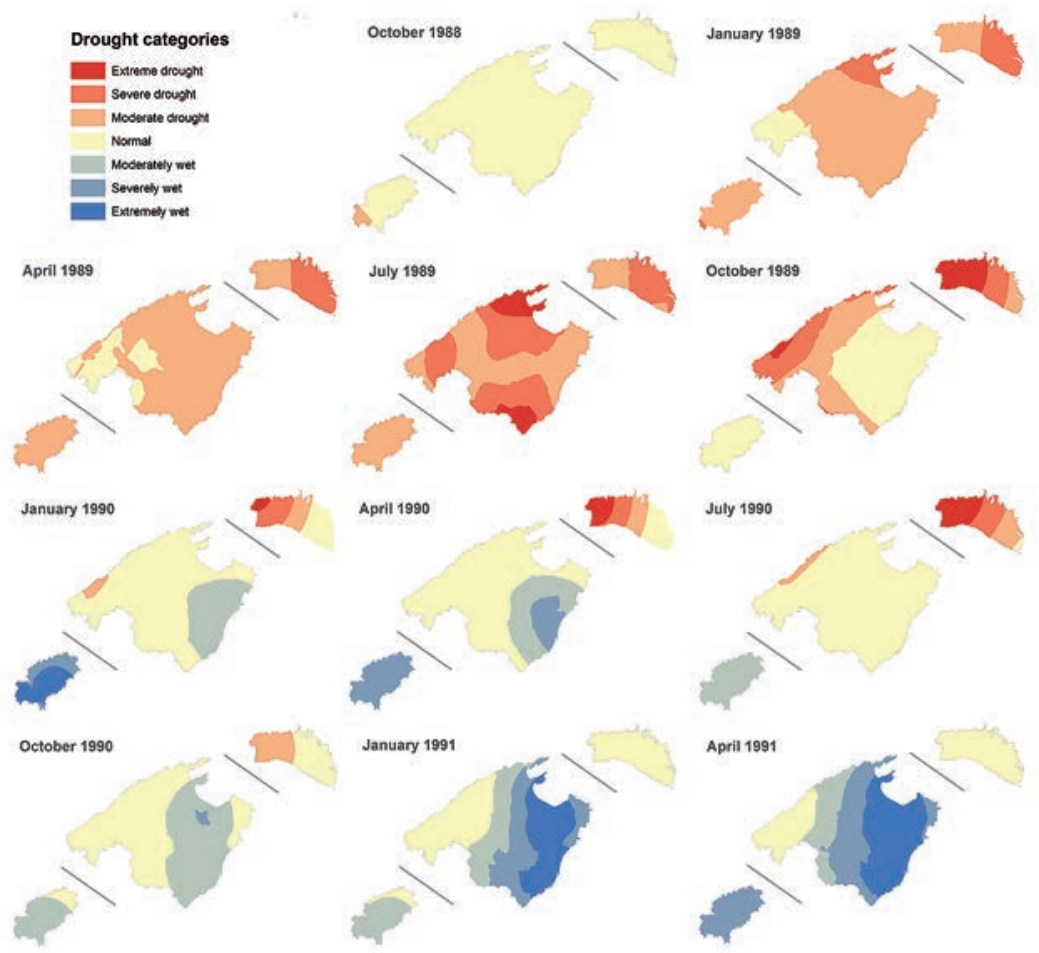

Figure 6. Spatial patterns of the SPI-12 series during 1999-2001 major drought episode.

\section{Discussion}

The Mediterranean region is a climate hot-spot where many uncertainties on the effects of climatic change remain unresolved (Diffenbaugh et al., 2007; García-Ruiz et al., 2011). There is a generalized agreement within the scientific community on the warming conditions predominant in most of the Mediterranean basin during last decades, where a general increase on average temperatures has been recorded (Repapis et al., 2004; Brunetti et al., 2006; Alpert et al., 2008; Camuffo et al., 2010; Homar et al., 2010). Nevertheless, past evolution and future projections for precipitation are more variable than those of temperature, and present a very high spatiotemporal variability (Sumner et al., 2003; Alpert et al., 2008; Philandras et al., 2011; Quintana-Seguí et al., 2011), which may create more complex drought patterns. In this sense, many studies have addressed meteorological drought patterns analysis within the western Mediterranean region using in-situ observations (Lana et al., 2001; Bonaccorso et al., 2003; VicenteSerrano et al., 2004; Vicente-Serrano, 2011; Di Lena et al., 2014) and, although they showed predominant drying conditions since the decade of 1970 , in most cases they did not found significant trends in the evolution of drought indices. A common finding of these studies was an extreme spatial variability of drought patterns within limited spatial 
extensions (e.g. Valencia region, Catalonia, Sicily), which were detected using a highdensity database. Thus, the use of big amounts of observational data allows the detection of complex drought patterns and has become a requirement when addressing drought analysis at the sub-regional level.

In this study, we focused on the analysis of meteorological drought patterns in the Balearic Islands using a very high-density database for the period 1974-2014. We based our analysis on the use of the SPI computed at the temporal scale of 12 months. The use of the SPI enabled us to perform a PCA using standardized variables, comparable in time and space, and thus to identify regions with homogeneous meteorological drought characteristics. The efficacy of this method was previously proved in several studies addressed in a close spatial context (Lana et al., 2001; Vicente-Serrano et al., 2004). The PCA performed quite well in our case, as the regionalization obtained showed highly coherent geographical patterns with well-defined natural boundaries (mainly mountain ranges and the separation by sea). The orographic effect created by the Tramuntana range is evident in the grouping obtained by the PCA. The observatories most correlated with PC1 integrated a coherent region including the Tramuntana range in Majorca and the entire island of Minorca, whereas PC2 is correlated with observatories located in Majorcan central and southern sectors (pluviometric shadow zone) and Ibiza. The PCA already showed its effectiveness for regionalization purposes based on climatic and hydrological features. For example, Lana et al. (2001) applied a PCA to SPI series in Catalonia and found a differentiated behavior of meteorological droughts between regions, closely related to the distribution of mountain ranges. In that case, the spatial distribution of the loadings of the first principal components coincided with the Llobregat valley and surroundings (PC1), the central basin (PC2), the pre-Pyrenees (PC3), the Pyrenees (PC4) and the Ebro valley (PC5). Moreover, Lorenzo-Lacruz et al. (2013b) used a PCA in order to obtain a regionalization of the Iberian Peninsula based on 187 standardized river flows series. Once again, mountain ranges played a prominent role in streamflow behavior and in the consequent spatial distribution of the loadings of selected principal components, corresponding to: the Iberian range and the plateau of Castile (PC1), the Duero basin (PC2 and PC3), the Ebro valley (PC4), the Pyrenees (PC5), the part of the Segura basin directly receiving water from the headwaters of the Tajo basin (PC7), the sectors of the Segura basin non-affected by Tajo-Segura water transfer (PC8) and Catalonian river basins (PC9).

The general patterns reported in this study for the evolution and occurrence of meteorological droughts in the Balearic Islands are consistent with the findings obtained in similar studies addressed in close spatial contexts: the drought episode affecting PC1 and recorded in 1983 was observed in Catalonia (Lana et al., 2001) and the 1989-1990 drought episode affecting PC1 was also observed in the north of the Iberian Peninsula (Vicente-Serrano, 2006a). Regarding PC2, the main drought episode occurred between 1999 and 2001 was also detected in the southeastern sector of the Iberian Peninsula (Vicente-Serrano, 2006a). However, the great drought which affected the Iberian Peninsula during 2004 and 2005 (García-Herrera et al., 2007), associated to a positive North Atlantic Oscillation phase, was not observed in the Balearic Islands, highlighting a different impact of teleconnection patterns on drought occurrence on the Balearic Islands, which may be object of future research. 
Analysis on drought episodes characteristics showed similar features in terms of intensity for both principal components. We did not find evidences on an enhancement of drought intensity during the study period. Nevertheless, we observed that the most intense episodes were the longest ones, suggesting that the most prolonged drought episodes in the region are hazardous in terms of its duration and the subsequent accumulated deficit, but also in terms of the extreme magnitude of the temporary shortage, which may threaten water supply during the touristic season. In terms of duration, we found a contrasted evolution between both principal components: whereas drought duration of the episodes registered in the northern sector of Majorca and Minorca (PC1) showed a decreasing trend, those episodes registered in the southern part of Majorca and Ibiza (PC2) showed an increasing trend in drought duration. These findings are partially consistent with precipitation decreasing trends observed by Homar et al. (2010) in the Balearic Islands, especially during spring, which may have exacerbated drought duration in the southern part of Majorca and Ibiza. In contrast, we observed a predominant humid period during the last decade in the Tramuntana mountain range and Minorca.

The analysis of drought spatial coverage revealed two main humid periods at the beginning and the end of the analyzed period, when drought affected area rarely exceeded $20 \%$ of the observatories, and one long lasting dry period interspersed between them (during the decade of 1980 and 1990), when the area under drought conditions was often above $70 \%$. The evolution of drought spatial coverage shown in this study is almost identical to the one observed in the region of Valencia (Vicente-Serrano et al., 2004). The heterogeneity observed in the genesis and spatial propagation of droughts over time confirms the view that no two droughts are identical, and that drought are not static (Wilhite, 2005). We showed that the core area of a drought can shift, and its spatial extent can expand and contract until its total disappearance. In consequence, the assessment and monitoring of individual drought episodes is of great relevance to the development of early warning systems and management strategies to mitigate the negative impacts of droughts. The great vulnerability of the Balearic Islands to droughts, induced by climatology, high population density and touristic pressure, may increase in a future scenario in which more frequent and intense drought episodes are expected to occur in the region (IPCC, 2014). Adaptation strategies that consider historical drought patterns should be adopted in order to balance the limited water availability and the expected growing population and increasing touristic rates.

\section{Conclusions}

This study provides a comprehensive analysis of meteorological droughts in the Balearic Islands between 1974 and 2014. The main findings can be summarized as follows:

The occurrence of droughts over the Balearic archipelago shows two contrasted temporal patterns, each one found over a specific area: the northern sector encompassing the Tramuntana mountain range in Majorca and the entire Minorca, and the southern sector, which includes the central plain of Majorca and Ibiza. 
In each of the two sectors droughts occurred independently over the period 19742014, except the 2000 drought episode which covered the whole region. The northern sector is characterized for a long period of time with sustained drought conditions between 1982 and 2002, and prevailing moist conditions over the last decade. In contrast the southern sector shows more alternation between dry and moist episodes over the study period.

The duration of independent drought episodes over the northern sector shows a decreasing trend while droughts over the southern sector shows a slight increase in duration. The intensity of droughts shows no clear trends over the study period.

The observation of two contrasted patterns in the evolution of drought over a small territory suggests the need for high resolution studies when assessing drought monitoring and analysis. In the Balearic Islands water availability is constantly threaten by meteorological conditions, high population density and touristic pressure, and our findings can contribute to an improved water planning that considers sub-regional drought variability.

\section{Acknowledgements}

We would like to thank the Spanish National Meteorological Agency (AEMET) for providing the data used in this study.

\section{References}

Agnew, C.T. 2000. Using the SPI to identify drought. Drought Network News 12, 6-12. Available at: http://digitalcommons.unl.edu/cgi/viewcontent.cgi?article=1000\&context=droughtnetnews.

Alexandersson, A. 1986. A homogeneity test applied to precipitation data. International Journal of Climatology 6, 661-675.

Alpert, P., Krichak, S.O., Shafir, H., Haim, D., Osetinsky, I. 2008. Climatic trends to extremes employing regional modeling and statistical interpretation over the E. Mediterranean. Global and Planetary Change 63, 163-170.

Bonaccorso, B., Bordi, I., Cancelliere, A., Rossi, G., Sutera, A. 2003. Spatial Variability of Drought: An Analysis of the SPI in Sicily. Water Resources Management 17, 273-296.

Briffa, K.R., van der Schrier, G., Jones, P.D. 2009. Wet and dry summers in Europe since 1750: evidence of increasing drought. International Journal of Climatology 29 (13), 1894-1905.

Camuffo, D., Bertolin, C., Barriendos, M., Dominguez-Castro, F., Cocheo, C., Enzi, S., Sghedoni, M., della Valle, A., Garnier, E., Alcoforado, M.-J., Xoplaki, E., Luterbacher, J., Diodato, N., Maugeri, M., Nunes, M.F., Rodriguez, R. 2010. 500-year temperature reconstruction in the Mediterranean Basin by means of documentary data and instrumental observations. Climatic Change 10, 1169-1199.

del Río, S., Herrero, L., Fraile, R., Penas, A. 2011. Spatial distribution of recent rainfall trends in Spain (1961-2006). International Journal of Climatology 31, 656-667.

Diffenbaugh, N.S., Pal, J.S., Giorgi, F., Gao, X., 2007. Heat stress intensification in the Mediterranean climate change hotspot. Geophysical Research Letters 34, L11706. Doi: 10.1029/2007GL030000. 
Di Lena, B., Vergni, L., Antenucci, F., Todisco, F., Mannocchi, F. 2014. Analysis of drought in the region of Abruzzo (Central Italy) by the Standardized Precipitation Index. Theoretical and Applied Climatology 115 (1-2), 41-52.

Esteban-Parra, M.J., Rodrigo, F.S., Castro-Díez, Y. 1998. Spatial and temporal patterns of precipitation in Spain for the period 1880-1992. International Journal of Climatology 18, 1557-1574.

European Environmental Agency 2001. Sustainable Water Use in Europe, Part 3. Extreme hydrological events: Floods and droughts. Environmental issue report 21. Available at: http://www.eea.europa.eu/publications/Environmental_Issues_No_21/at_download/file.

Fiorillo, F., Guadagno, F.M. 2010. Karst Spring Discharges Analysis in Relation to Drought Periods, Using the SPI. Water Resources Management 24 (9), 1867-1884.

García-Herrera, R., Hernández, E., Barriopedro, D., Paredes, D., Trigo, R.M., Trigo, I., Mendes, M.A. 2007. The Outstanding 2004/05 Drought in the Iberian Peninsula: Associated Atmospheric Circulation. Journal of Hydrometeorology 8, 483-498.

García-Ruiz, J.M., López-Moreno, J.I., Vicente-Serrano, S.M., Lasanta-Martínez, T., Beguería, S. 2011. Mediterranean water resources in a global change scenario. Earth-Science Reviews 105 (3-4), 121-139.

Giménez, J., Gelabert, B., Sàbat, F. 2007. The relief of the Balearic Islands. Enseñanza de las Ciencias de la Tierra 15 (2), 175-184.

Giorgi, F., Lionello, P. 2008. Climate change projections for the Mediterranean region. Global and Planetary Change 63, 90-104.

González-Hidalgo, J.C., Brunetti, M., de Luis, M. 2011. A new tool for monthly precipitation analysis in Spain: MOPREDAS database (monthly precipitation trends December 1945-November 2005). International Journal of Climatology 31 (5), 715-731.

Guttman, N.B. 1999. Accepting the standardized precipitation index: a calculation algorithm. Journal of the American Water Resources Association 35, 311-322.

Hannaford, J., Lloyd-Hughes, B., Keef, C., Parry, S., Prudhomme, C. 2011. Examining the largescale spatial coherence of European drought using regional indicators of precipitation and streamflow deficit. Hydrological Processes 25, 1146-1162.

Hayes, M., Svoboda, M., Wall, N., Widhalm, M. 2011. The Lincoln declaration on drought indices. Universal Meteorological Drought Index Recommended. Bulletin of the American Meteorological Society, April 2011, 485-488. Doi: 10.1175/2010BAMS3103.1.

Hirschi, M., Seneviratne, S., Alexandrov, V., Boberg, F., Boroneant, C., Christensen, O.B., Formayer, H., Orlowsky, B., Stepanek, P. 2011. Observational evidence for soil-moisture impact on hot extremes in southeastern Europe. Nature Geoscience 4, 17-21.

Homar, V., Ramis, C., Romero, R., Alonso, S. 2010. Recent trends in temperature and precipitation over the Balearic Islands (Spain). Climatic Change 98, 199-211.

Hof, A., Schmitt, T. 2011. Urban and tourist land use patterns and water consumption: Evidence from Mallorca, Balearic Islands. Land Use Policy 28 (4), 792-804.

IPCC 2014. Climate Change 2014: Synthesis Report. In R.K. Pachauri, L.A. Meyer (eds.), Contribution of Working Groups I, II and III to the Fifth Assessment Report of the Intergovernmental Panel on Climate Change, IPCC, Geneva, Switzerland, 151 pp.

Jansa, A. 2014. El clima de les Illes Balears. Palma de Mallorca, Lleonard Muntaner.

Jolliffe, I. 2005. Principal component analysis. Chichester, John Wiley \& Sons.

Lana, X., Serra, C., Burgueño, A. 2001. Patterns of monthly rainfall shortage and excess in terms of the Standardized precipitation index for Catalonia (NE Spain). International Journal of Climatology 21, 1669-1691. 
Lana, X., Martínez, M.D., Burgueño, A., Serra, C., Martín-Vide, J, Gómez, L. 2006. Distributions of long dry spells in the Iberian Peninsula, years 1951-1990. International Journal of Climatology 26, 1999-2021.

Lavorel, S.R., Candell, J., Rambal, S., Terradas, J. 1998. Mediterranean terrestrial ecosystems: research priorities on global change effects. Global Ecology and Biogeography 7, 157-166.

Lorenzo-Lacruz, J., Vicente-Serrano, S.M., López-Moreno, J.I., Beguería, S., García-Ruiz, J.M., Cuadrat, J.M. 2010. The impact of droughts and water management of various hydrological systems in the headwaters of the Tagus river (central Spain). Journal of Hydrology 386, 13-26.

Lorenzo-Lacruz, J., Vicente-Serrano, S.M., González-Hidalgo, J.C., López-Moreno, J.I., Cortesi, N. 2013a. Hydrological drought response to meteorological drought in the Iberian Peninsula. Climate Research 58, 117-131.

Lorenzo-Lacruz, J., Morán-Tejeda, E., Vicente-Serrano, S.M., López-Moreno, J.I. 2013 b. Streamflow droughts in the Iberian Peninsula between 1945 and 2005: spatial and temporal patterns. Hydrology and Earth System Sciences 17, 119-134.

McKee, T.B.N., Doesken, J., Kleist, J. 1993. The relationship of drought frequency and duration to time scales. In Eight Conference on Applied Climatology, American Meteorological Society, Anaheim, CA, pp. 179-184.

Mishra, A.K., Singh, V.P., 2010. A review of drought concepts. Journal of Hydrology 391, $202-$ 216.

Morán-Tejeda, E., Ceglar, A., Medved-Cvikl, B., Vicente-Serrano, S.M., López-Moreno, J.I., González-Hidalgo, J.C., Revuelto, J., Lorenzo-Lacruz, J., Camarero, J., Pasho, E. 2013. Assessing the capability of multi-scale drought datasets to quantify drought severity and to identify drought impacts: an example in the Ebro Basin. International Journal of Climatology 33 (8), 1884-1897.

Morata, A., Martín, M.L., Luna, M.Y., Valero, F. 2006. Self-similarity patterns of precipitation in the Iberian Peninsula. Theoretical and Applied Climatology 85, 41-59.

Nicault, A., Alleaume, S., Brewer, S., Carrer, M., Nola, P., Guiot, J. 2008. Mediterranean drought fluctuation during the last 500 years based on tree-ring data. Climate Dynamics 31, 227-245.

Obasi, G.O.P. 1994. WMO's role in the International Decade for natural disaster reduction. Bulletin of the American Meteorological Society 75, 1655-1661.

Osca, J., Romero, R., Alonso, S. 2013. Precipitation projections for Spain by means of a weather typing statistical method. Global and Planetary Change 109, 46-63.

Palutikof, J.P., Holt, T. 2004. Climate change and the occurrence of extremes: some implications for the Mediterranean Basin. In A. Marquina (ed.), Environmental Challenges in the Mediterranean 2000-2050. Kluwer Academic Publishers, pp. 61-73.

Pasho, E., Camarero, J.J., de Luis, M., Vicente-Serrano, S.M. 2011. Impacts of drought at different time scales on forest growth across a wide climatic gradient in north-eastern Spain. Agricultural and Forest Meteorology 151 (12), 1800-1811.

Patel, N.R., Chopra, P., Dadhwala, V.K. 2007. Analyzing spatial patterns of meteorological drought using standardized precipitation index. Meteorological Applications 14, 329-336.

Philandras, C.M., Nastos, P.T., Kapsomenakis, J., Douvis, K.C., Tselioudis, G., Zerefos, C.S. 2011. Long term precipitation trends and variability within the Mediterranean region. Natural Hazards and Earth System Sciences 11, 3235-3250.

Quintana-Seguí, P., Habets, F., Martin, E. 2011. Comparison of past and future Mediterranean high and low extremes of precipitation and river flow projected using different statistical downscaling methods. Natural Hazards and Earth System Sciences 11, 1411-1432.

Quiring, S.M. 2009. Developing objective operational definitions for monitoring drought. Journal of Applied Meteorology and Climatology 48, 1217-1229. 
Quiroga, S., Garrote, L., Iglesias, A., Fernández-Haddad, Z., Schlickenrieder, J., de Lama, B., Mosso, C., Sánchez-Arcilla, A. 2011. The economic value of drought information for water management under climate change: a case study in the Ebro basin. Natural Hazards and Earth System Sciences 11, 643-657.

Repapis, C.C., Philastras, C.M. 2004. A note on the air temperature trends of the last 100 years as evidenced in the eastern Mediterranean time series. Theoretical and Applied Climatology 39, 93-97.

Richman, M.B. 1986. Rotation of principal components. Journal of Climatology 6 (3), 293-335.

Rodrigo, F.S., Trigo, M. 2007. Trends in daily rainfall in the Iberian Peninsula from 1951 to 2002. International Journal of Climatology 27, 513-529.

Sims, A.P., Niyogi, D.S., Raman, S. 2002. Adopting drought indices for estimating soil moisture: A North Carolina case study. Geophysical Research Letters 29 (8), 1183.

Sumner, G.N., Romero, R., Homar, V., Ramis, C., Alonso, S., Zorita, E. 2003. An estimate of the effects of climate change on the rainfall of Mediterranean Spain by the late twenty first century. Climate Dynamics 20, 789-805.

Vicente-Serrano, S.M., González-Hidalgo, J.C., De Luis, M., Raventós, J. 2004. Drought patterns in the Mediterranean area: the Valencia region (eastern Spain). Climate Research 26, 5-15.

Vicente-Serrano, S.M., López-Moreno, J.I. 2005. Hydrological response to different time scales of climatological drought: an evaluation of the Standardized Precipitation Index in a mountainous Mediterranean basin. Hydrology and Earth System Sciences 9, 523-533.

Vicente-Serrano, S.M. 2006a. Spatial and temporal analysis of droughts in the Iberian Peninsula (1910-2000). Hydrological Sciences Journal 51 (1), 83-97.

Vicente-Serrano, S.M. 2006b. Differences in spatial patterns of drought on different time scales: an analysis of the Iberian Peninsula. Water Resources Management 20, 37-60.

Vicente-Serrano, S.M., López-Moreno, J.I., Drumond, A., Gimeno, L., Nieto, R., Morán-Tejeda, E., Lorenzo-Lacruz, J., Beguería, S., Zabalza, J. 2011. Effects of warming processes on droughts and water resources in the NW Iberian Peninsula (1930-2006). Climate Research 48, 203-212.

Vicente-Serrano, S.M., Beguería, S., Lorenzo-Lacruz, J., Camarero, J.J., López-Moreno, J.I., Azorin-Molina, C., Revuelto, J., Morán-Tejeda, E., Sánchez-Lorenzo, A. 2012. Performance of drought índices for ecological, agricultural and hydrological applications. Earth Interactions 16 (10), 1-27.

Wilhite, D.A. 2005. Drought and water crises, Science, technology, and management issues. Taylor and Francis, Oxford, 406 pp.

White, D., Richman, H., Yarnal, B. 1991. Climate regionalization and rotation of principal components. International Journal of Climatology 11, 1-25.

World Meteorological Organization 2011. Guide to meteorological practices. WMO $\mathrm{n}^{\mathrm{o}} 100$, Geneva. 